\title{
İkinci Yüzyılında İşbirliği ve Çatışma Sarmalında Türk- Amerikan İlişkileri
}

\author{
DOI: 10.26466/opus.532884
}

\author{
Zafer Akbaş ${ }^{*}$ - Ahmet Hüsrev Çelik* ${ }^{* *}$ Melih Duman ${ }^{* * *}$ \\ *Doç. Dr., Düzce Üniversitesi Akçakoca Bey Siyasal Bilgiler Fakültesi, Düzce/ Türkiye \\ E-Posta: zaferakbas@duzce.edu.tr ORCID: 0000-0002-9974-5576 \\ ** Dr. Öğr. Üyesi, Düzce Üniversitesi Akçakoca Bey Siyasal Bilgiler Fak., Düzce, Türkiye \\ E-Posta: ahmetcelik@duzce.edu.tr ORCID: 0000-0003-4199-2168 \\ ***Dr., Öğr. Üyesi, Aksaray Üniversitesi İletişim Fakültesi Aksaray / Türkiye \\ E-Posta: melihduman@aksaray.edu.tr ORCID: 0000-0001-6861-615X
}

\section{Öz}

Bu çalışma ilk kez 19. yüzyılda gündeme gelen Türk-Amerikan ilişkilerini tarihsel süreç içerisinde çatışma ve işbirliği temelinde siyasal, ekonomik ve askeri olarak ele almaktadır. Yaklaşık iki yüzyıllık geçmişe sahip Türk-Amerikan ilişkileri çoğu zaman bölgesel ve küresel olaylarm etkisinde gelişmiştir. İki ülke arası ilişkiler dönemsel olayların etkisi altında kalmıştır. Bu doğrultuda çalışma tarihsel süreçte Türk-Amerikan ilişkilerinin nasıl bir gelişme gösterdiğini, işbirliği ve çatışma ekseninde ortaya koymaya çalışmaktadır. ABD, Türkiye'nin yakın coğrafyasına yönelik aktif dış politika izlemektedir. Çalışmada, aktörler arası ilişkinin niteliğini ABD'nin bölgesel ve konjonktürel çıkar ve politikalarının belirlediği savunulmaktadır. ABD, sadece Türkiye ile değil, bölgesel diğer aktörlerle de konjonktürel nedenlerle işbirliği ve çıkar çatışması yaşamaktadır. Ancak $A B D$ ve Türkiye çıkar çatışması yaşadığı durumlarda da ilişkilerini tamamen kesmeden sürdürmüştür. Bu bağlamda Türkiye ve ABD, bölgesel ve uluslararası sorunlarda birlikte hareket ederek işbirliği gerçekleşmiştir. Çalı̧̧mada öne sürülen iddiaların doğruluğunun araştırlması için "Misyonerlik faaliyetleri", "SSCB Tehlikesi", "Truman Doktrini", "Kore Savaşı", "Füze Krizi”, "Kıbrıs Meselesi”, "1 Mart Tezkeresi”, "Çuval olayı" gibi olaylar üzerine odaklanılmıştır. Kriz dönemlerinde iki ülkenin çatıştı̆̆̆, diğer durumlarda ise işbirliği iç̧inde olduğu sonucuna ulaşılmıştır.

Anahtar Kelimeler: Türkiye, ABD, Çatışma, İşbirliği, Dış Politika 


\title{
Turkish-American Relations in the Second Century of Cooperation and Conflict Spiral
}

\begin{abstract}
This study first examines the Turkish-American relations dating back to the 19th century on the context of historical process based on the conflict and cooperation in the sense of politics, economy and military. Turkish-American relations with nearly two centuries of history have often been improved by the shadow of regional and global events. The relations between the two countries remained under the reactions of conjectural events. That's why the study tries to depict how the development of Turkish-American relations in the historical process is on the axis of cooperation and conflict. The United States also follows a proactive foreign policy towards Turkey's near geography. The study advocates that the nature of the relationship between the actors has been determined by the regional and cyclical interests and policies of the USA. It is a fact that USA has not only dilemma of cooperation and conflict with Turkey but also with other regional actors due to conjectural reasons. However, despite the case of overlapping of interest conflicts, Turkey and USA has been successful to keep in relationship. In this context, Turkey and the United States, have been improved mutually cooperation by acting together in regional and international problems. In order to check the accuracy of the claims put forward in the study, specific cases like "Missionary Activities", "USSR Hazard", "Truman Doctrine", "Korean War", "Missile Crisis", "Cyprus İssue", "March 1" and "The Hood Event" have been focused. It was concluded that both countries were in conflict in the era of crisis whereas they had cooperation in the rest of cases.
\end{abstract}

Keywords: Turkey, USA, Conflict, Cooperation, Foreign Policy 


\section{Giriş}

1826 yılında Osmanlı karasularını Amerika Birleşik Devletleri (ABD) ticaret gemilerinin ilk kez ziyaret etmesiyle tesis edilen Türk-Amerikan ilişkileri, yaklaşık olarak iki yüzyıllık bir süreci geride bırakmışır. Osmanlı Devleti döneminde filizlenen ikili ilişkiler, 1830 yılında resmi bir hüviyet kazanmış, iki ülke arasında ticari ürün satışı, misyoner okulları gibi konularda yürütülen ilişkiler, I. Dünya Savaşı sırasında kesintiye uğramıştır. Daha sonra tekrar başlayan ilişkiler, inişli çıkışlı bir seyir izleyerek kimi zaman işbirliği kimi zaman ise çatışma sarmalında bir süreç göstermiştir.

II. Dünya Savaşı sonrasında Türkiye'nin milli güvenlik algılamalarında tanımladığı tehditler nedeniyle ABD ile ittifakı gündeme getirirken $\mathrm{ABD}$ ise Ortadoğu başta olmak üzere Monroe Doktrini sonrasında yeniden şekillendirdiği diş politikasında aktif bir politika sürdürebilmek üzere Türkiye ile yakın ilişkiler kurmuştur. SSCB tehlikesi karşısında Türk-Amerikan ilişkileri Türkiye'nin NATO'ya girmesiyle birlikte askeri işbirliği noktasına ulaşmıştır. Bu eksende çalışma, Türk-Amerikan ilişkilerinin tarihsel süreç içerisinde, 1800'li yıllarda başlayan yapısının nasıl bir gelişme çizgisi sürdürdügünü ortaya koymaya çalışmakta olup, Osmanlı ve Cumhuriyet dönemi olarak incelenmiştir. Osmanlı dönemi ilişkilerin seyri sebebiyle daha dar kapsamlı bir değerlendirme açısından ele alınırken Cumhuriyet dönemi, II. Dünya Savaşı sonuna kadar olan dönem, Soğuk Savaş Süreci, Soğuk Savaş Sonrası dönem ve son olarak da 2000'li yıllar olarak bölümlenmiştir.

\section{Osmanlı Devleti Döneminde Türk - Amerikan İlişkileri}

Amerika Birleşik Devletleri'nin (ABD) kurulduğu tarihten itibaren Akdeniz ticareti ile yakından ilgilenmesi Türkiye ile tarihsel ilişkilerinin ticari bir zeminde başlamasını sağlamıştır. 1800'lerden sonra Amerikan ticaret gemileri dünya ticaretinde yerini almak ve pazarlarını geliştirmek üzere İzmir'e uğramaya başlamıştır. 1800'li yıllar itibariyle Amerikan ticaret gemileri, Akdeniz'de serbest ticaret yapmak üzere Osmanlı Devleti'ne bağlı bir eyalet olan, Cezayir, Tunus ve Trablusgarp'ı içeren Garp Ocakları'na senelik bir vergi ile mühimmat ve kiymetli hediyeler vermek mecburiyetindeydi. ABD’nin Garp Ocakları üzerinden Osmanlı Devleti ile başlayan 
münasebetleri, ticaret gemilerinin başta İzmir olmak üzere, Osmanlı limanlarına uğramaları ile sürmüştür (Erol, 1988, s.7-9). Osmanlı ile ABD arasında gerçekleştirilen ilk anlaşma 7 Mayıs 1830 tarihinde imzalanan 'Ticaret ve Dostluk' anlaşmasıdır. ABD ile ticaret anlaşması yapma fikrinin temelinde, 1826 yılında Türk suların ziyaret eden ABD donanmasının beğenilmesi yer almıştır (Doğan, 1996, s.21-22). Özellikle 1827 Navarin baskını sırasında Osmanlı donanmasının İngiliz, Fransız ve Ruslar tarafından yakılması sebebiyle İngiltere ve Fransa'ya alternatif ittifak aray1şına girilmiştir (Şafak, 2003, s.11). Bu doğrultuda 1830 yılında imzalanan anlaşma ile Osmanlı donanmasının ABD' de yaptırılacak gemilerle güçlendirilmesi fikri hâsıl olmuşsa da bir netice alınamamıştır (Doğan, 1996, s.2122). Donanma konusunda ABD'den istediği neticeyi elde edemeyen Osmanlı, 1839 yılında ilan edilen Tanzimat Ferman ile askeri sahada modernleşme konusunda bir ivme sağlamıştır. Osmanlı Devleti, Ordunun savaş kabiliyetini yükseltmek üzere modern silahlarla donatılması kapsamında Amerika'ya gönderdiği görevliler vasıtasıyla, ABD hafif silahlarını satın alarak ordu envanterine dâhil etmiştir. ABD ile Osmanlı arasında gerçekleşen silah ticareti ile Osmanl-ABD ilişkileri önemli bir noktaya gelmişse de XIX. Yüzyılda Almanya'nın Osmanlı için artan önemi karş1sında ABD'nin yerini Almanya almıştır (Gencer v.d., 2008, s.255-257).

Osmanlı Devleti, ABD tezgâhlarından donanmayı modernize etmek üzere istifade edememiş, fakat $\mathrm{ABD}$, imzaladığı anlaşma ile kısa süre içerisinde Akdeniz ve Karadeniz'e ticari emtia ile misyonerler taşımaya başlamıştır. İki ülke arasındaki ilişkiler, XIX. Yüzyılın ikinci yarısından itibaren önemli bir aşama kaydetmiştir (Şafak, 2003, s. 11). ABD kısa süre içerisinde Osmanlı sınırları içerisinde başladığı faaliyetleri hızlandırmıştır. $\mathrm{Bu}$ süreçte Amerika için misyoner meselesi, ticaret anlaşması kadar önemli olan bir diğer mesele olmuştur (Fendoğlu, 2002, s.221-223). Kisa bir süre içerisinde örgütlenen misyoner hareketi, Beyrut'ta bir üniversite ile Cirad isminde bir de kolej kurmuştur. Üniversite Ortadoğu'daki Amerikan okullarında görev yapacak misyoner öğretmenleri, Cirad Koleji ise köylerde görev alacak misyonerleri eğitmiştir (Doğan, 1996, s.60). Amerikan misyonerlerinin faaliyetlerine karşı Osmanlı Devleti, hiçbir tepki göstermemiş, geleneksel tutumu olan gayri Müslimlere din ve vicdan hürriyeti çerçevesinde davranmıştır. Osmanlı, siyasete karışmamaları şartıyla 
misyonerlik faaliyetlerini ve okullarını serbest bırakmıştır (Fendoğlu, 2002, s.225).

Ticari sahada başlayan ve misyonerlik faaliyetleriyle ilerleyen Osmanlı-Amerikan ilişkileri, kısa süre içerisinde bir sorun yumağına dönüşmüştür. Osmanlı Devleti'nde XIX. Yüzyıl boyunca milliyetçilik ekseninde meydana gelen azınlık ayaklanmaları sırasında, ABD Hükümeti ve kamuoyunun tutumu, Türk-Amerikan ilişkilerinin seyrini etkilemiştir. Bu seyir üç aşamada değerlendirilmelidir. İlk olarak azınlık ayaklanmaları konusuyla doğrudan bağlantılı olan Amerikan misyonerleri ve bazı ABD'li diplomatların yürüttükleri propagandanın sonucu olarak ABD'deki Türk imajı son derece menfi bir hal almıştır. İkinci olarak ayaklanmalar sırasında iki ülke arasında yakın bir siyasi ilişki sağlanamamıştır. Üçüncü olarak ise azınlık olaylarına destek vererek zaman zaman karışan Amerikan Misyonerleri, Osmanlı Devleti'nin gözünde sakıncalı kişiler haline gelmiştir. Böylece misyonerler üzerindeki denetim arttırılmış, bu durum ise $A B D$ 'yi rahatsız etmiş ve iki ülke arasındaki ilişkilere olumsuz bir biçimde yansımıştır (Erhan, 2001, s.337-339).

XIX. Yüzyıl içerisinde meydana gelen Ermeni meselesi, misyonerlik faaliyetleri, diğer azınlık ayaklanmaları gibi gelişmeler, Osmanlı-Amerikan İlişkilerini olumsuz etkilemiştir. 'Chester Demiryolu projesi' gibi ticari atılımlarla, Osmanlı Devleti - ABD ilişkilerine yeniden ivme kazandırılmak istenmiştir, fakat 1914 yılında meydana gelen I. Dünya Savaşı, Osmanl1Amerikan ilişkilerini sona erdirmiştir. Savaşın başında resmi olarak Osmanlı - ABD ilişkileri sürse de Osmanlı'nın kapitülasyonları kaldırmasına ABD'nin itirazı, Yunanistan'a savaş gemisi satması, Türk karasularına savaş gemisi göndermesi neticesinde ilişkiler gerilmiştir. Fendoğlu, 2002, s. 242-243) ABD’nin 1917 yılında savaşa girmesiyle birlikte ikili ilişkiler diplomatik olarak tamamen kesilmiştir (Armaoğlu, 1991, s.19).

\section{Cumhuriyet Döneminde Türk- Amerikan İlişkileri}

Cumhuriyet'in ilanı sonrası karşılıklı olarak iki devletin adım atması üzerine on yıllık bir aradan sonra 1927 yılında (Erhan, 2001, 338) eş zamanlı olarak ilişkiler büyükelçilik seviyesinde tekrar başlamıştır (Armaoğlu, 1991, s.110-111). Bu doğrultuda çalışma Cumhuriyet döneminde işbirliği ve çatışma sarmalında üç temel kategoride II. Dünya Savaşı sonuna kadar 
olan dönem, Soğuk Savaş dönemi, Soğuk Savaş sonrası dönem olarak değerlendirilmektedir.

\subsection{Dünya Savaşı'nın Sonuna Kadar Olan Dönem: 1923 - 1945 Dönemi}

Türkiye-ABD ilişkileri, resmi kanalların kurulmasından sonra II. Dünya Savaşı'nın bitmesine kadar işbirliği sürecinde yürütülmüştür. Bu durumun oluşmasında gerek ABD’nin I. Dünya Savaşı'ndan sonra kıtasına çekilmiş olması, gerekse Türkiye ile ABD arasında Osmanlı döneminden gelen ihtilaflı konuların kalmamış olması ana etkendir. Ayrıca Cumhuriyet idarecilerinin yeni ideali olan çağdaşlaşmak, Batılılaşmak düşüncesi için ABD oldukça önemli bir partner olarak görülmüştür (Uslu, 2003, s.16-17).

Türkiye'nin ABD'ye yönelik bakış açısının müspet olmasına rağmen, fiziki ve siyasal şartlar ABD-Türkiye ilişkilerinin istenilen düzeyde gerçekleştirilmesini etkilemiştir. Özellikle Türkiye ile ABD arasındaki ekonomik, politik ve kültürel işbirliğinin zayıflığı bu durumun temel nedeni olmuştur. Uluslararası sistemde İngiltere' nin ağırlığının Türkiye için önemli bir pozisyon tutması, Türkiye'nin bu dönemde -infiratçılık politikasına dönmüş olan- ABD'yi önemli bir müttefik olarak algılamasının önüne geçmiştir. İki dünya savaşı arasında Türkiye ile ABD ilişkilerini etkileyen iki temel olaydan söz edilebilir. Bunlardan ilki henüz diplomatik ilişkilerin yeni başladığı bir evrede 1928 yılında yaşanmıştır. Bursa Amerikan Kız Koleji'nde bazı Müslüman öğrencilerin din değiştirmesi üzerine patlak varan hadise, kısa süre içerisinde Türk kamuoyunda infiale neden olmuştur. Çıkan olaylar nedeniyle okulun kapatılmasına, ABD şiddetle itiraz etmiştir. Amerikan Koleji vakasının kapatılmasından sonra ABD-Türk ilişkileri ile ilgili ikinci konu gündeme gelmiştir. 1929 yılında her iki devlet arasında imzalanan ticaret anlaşmasından sonra Türkiye, 1931 yılında Şükrü Saraçoğlu'nu Amerika malî çevreleriyle Türkiye'ye yatırım yapmaya ikna ve 100 milyon dolarlık bir kredi temin etmek üzere $A B D^{\prime} y e$ yollamıştır. Fakat Türkiye-ABD ilişkilerini geliştirecek önemli bir adım sayılan Saraçoğlu gezisi, Türkiye'ye istediklerini sağlayamamıştır (Ülman, 1961a, s.16-17).

II. Dünya Savaşı'nın patlak vermesi ve bir süre sonra ABD'nin infiratçılık politikasından ayrılarak savaşa dâhil olması, Türkiye-ABD ilişkile- 
rinde yeni bir safha açmıştır. Türkiye-ABD ilişkilerini II. Dünya Savaşı içerisinde iki safhada inceleyebiliriz. İlk olarak 1941 yılında ABD'nin fiilen savaşa girmesine kadar olan dönemde Türkiye-ABD ilişkileri, tarafların resmi olarak karşı karşıya gelmemeleri dolayısıyla büyük bir oranda işbirliği sürecinde ilerlemiştir. Savaş başında ve içerisinde Türkiye-ABD ilişkilerini ilgilendiren temel konu ticari ilişkiler olmuştur. Fakat savaşın tüm dünyada yayılması karşısında, ABD savaşı yakından takip ederek II. Dünya Savaşı için kilit bir mevkide bulunan Türkiye ile daha yakından ilgilenmiştir (Karakaş, s.48-49). II. Dünya Savaşı içerisindeki ilişkilerin ikinci dönemi ise ABD'nin 1941 yılında Müttefikler safında savaşa girmesi ve öncesinde yaşanmıştır. Türkiye'nin savaş boyunca sürdürdüğü 'savaşa katılmadan Türkiye'nin toprak bütünlüğünü korumak' hedefi (Weisband, 1974, s.9, 19) müttefikler tarafından Almanya ile kendi aralarında gidiş gelişler yaşadığı zannına sebep olmuştur. Bu doğrultuda ABD, Türkiye'nin Almanya ile saldırmazlık anlaşması imzalamış olmasına tepki olarak 'Ödünç Verme ve Kiralama Kanunu' çerçevesinde yardımı kesmiştir. Fakat bu dönemde İngiltere üzerinden gerçekleşen Türkiye-ABD ilişkileri, W. Churchill'in girişimiyle yardımın geri verilmesini sağlamıştır. ABD'nin resmen savaşa dâhil olmasından sonra ise Türkiye-ABD ilişkilerinin en önemli maddesi, Türkiye'nin Almanya'ya karşı müttefikler yanında savaşa katılması olmuştur. 1943 yılından sonra ise ABD bu politikasından vazgeçerek Türkiye'nin savaş dışı kalması fikrinde İngiltere ve Sovyet Rusya' dan farklı düşünmeye başlamıştır. Savaşın sonu yaklaştıkça özellikle 4-11 Şubat 1945 Yalta Konferansı sonrası şekillenmekte olan yeni Avrupa ve Dünya Politikaları içinde Türkiye, Hitler Almanya'sından hızla uzaklaşırken ABD'ye yakınlaşmıştır (Gözen, 2012, s.381-382).

\subsection{Soğuk Savaş Döneminde Türk-Amerikan İlişkileri}

ABD'nin II. Dünya Savaşı'na aktif olarak dahil olmasıyla birlikte nötr bir halden aktif bir işbirliği sürecine evrilen Türkiye-ABD ilişkileri, ABD'nin savaştan sonra yeniden infiratçılık politikasına dönecek olmasından kaynaklanan beklenti sebebiyle sürüncemede kalmıştır. II. Dünya Savaşı sonrasında Türk-Amerikan İlişkilerini belirleyen iki temel parametre vardır. Bunlardan ilki İngiltere'nin Türk dış politikasındaki önemini sürdürmesidir. İkincisi ise savaşın Avrupa üzerinde kazananı olan Sovyet Sosyalist 
Cumhuriyetler Birliği'dir. SSCB, Türkiye ile imzaladığı 17 Aralık 1925 tarihli ‘Dostluk ve Tarafsızlık' anlaşmasını 1945 yılının Mart ayında yenilemeyeceğini bildirerek Türk dış politikası için SSCB tehlikesinin başladığının işaretini vermiştir (Toker, 1971, s.5, 8-9).

Türkiye, Sovyet Rusya karşısında kaldığı zor durumda bağımsızlığını ve toprak bütünlügünü korumaya çalışırken, SSCB'ye karşı destek araması zorunlu hale gelmiştir. İngiltere'nin durumu göz önüne alındığında Türkiye için ortaya çıkan seçeneğin ABD olması kaçınılmazdı. Fakat ABD, bu dönemde yeniden kıtasına çekilmeyi planlıyordu ve ABD için SSCB henüz bir tehdit olarak görülmüyordu. I. Dünya Savaşının hatalarını tekrarlamak istemeyen müttefikler, savaş sonrası dönemi belirlemek için Yalta'dan sonra Potsdam'da ABD, İngiltere ve SSCB'nin katıldığı bir konferans tertip ettiler. Konferans, savaş sonrası müttefiklerin arasındaki problemlerin görünür olmaya başladığı bir konferans olmuştur (Byrnes, 1948, 117-118). Potsdam'da müttefikler arasındaki temel problem Sovyetlerin başta Türkiye olmak üzere genişleme eğilimine, İngiltere'nin karşı durması olmuştur. SSCB ile İngiltere arasında ortaya çıkan çatışmanın nedeni ise SSCB'nin Boğazlar ile ilgili talebidir. Konferansta iyice gün yüzüne çıan Sovyet emelleri karşısında, ABD daha belirsiz bir tarzda hareket etmeye başlamıştır. ABD'nin özellikle Japonya ile savaşı sürdürüyor olması, Sovyet Rusya'ya olan gereksinimini ortaya çıarıyordu. Bu sebeple SSCB'nin Boğazlarla ilgili talebini daha çok ticari bir perspektiften değerlendiren $\mathrm{ABD}$, Japonya'da savaşı bitirmesinden sonra Boğazların durumuna dair Türkiye bir nota vermiştir. ABD bu notada Boğazların fiilen Türklerin kontrolü altında kalmasını tavsiye ederek (Ayın Tarihi, 1945, s.70) Sovyetler yerine Türkiye'den yana ağırlığını koymaya başlamıştır. ABD'nin Boğazlar ile ilgili kararı önemli bir gelişme olarak kabul edilse de Türkiye açısından müttefik olarak algılanması için oldukça erken bir dönemdir.

Güvenlik meselesinin ciddi olarak tartışıldığı bu dönemde (Aydın, s.127) II. Dünya Savaşı sonrasında Türkiye-ABD ilişkilerinin belirleyicisi SSCB'nin Balkanlar ve Ortadoğu'da ABD ile karşı karşıya gelmesi olmuştur. İngiltere'nin SSCB'ye yönelik tavrına rağmen ABD'nin açıça Sovyet karşıtı görüş ortaya koyması, İran krizi sırasında ortaya çıkmıştır. SSCB'nin 1945 Mart'ında Azerbaycan sınırına girip İran'a doğru ilerlemesi ile ABD nezdinde Türkiye'nin konumu da oldukça önemli bir hal 
almıştır. Sovyet ilerleyiş̧i, Türkiye'nin Doğu Akdeniz ve Ortadoğu'daki konumunu ABD açısından oldukça önemli bir noktaya taşımıştır (McGee, 1992, s.49-51).

Türkiye, altı hafta süren İran krizi neticesinde, dış politikasında Sovyetlere karşı denge unsuru sağlayacak Batı'nın desteğini kazanmıştır. ABD'nin Türkiye'ye verdiği desteğin ilk göstergesi $A B D$ 'de vefat eden Türk diplomat Münir Ertegün'ün cenazesinin Missouri savaş gemisi ile Türkiye'ye getirilmesi olmuştur (Ayın Tarihi, Nisan 1946, s.52-53). Missouri savaş gemisinin SSCB'nin İran'da Mehabad Kürt Cumhuriyeti ile Özerk Azerbaycan'ı kurulduğu bir zamanda Türkiye'yi ziyaret etmesi, Sovyetlere yönelik oldukça önemli bir manevra olmuştur. Truman, İran'ın Sovyet kontrolüne geçmesi halinde, Türkiye'nin dayanma gücünün kalmayacağından endişe ediyordu. $\mathrm{Bu}$ sebeple Missouri'nin ziyareti ABD'nin tepkisini ve Türkiye'nin yanında olduğunu göstermek üzere bir firsat olmuştur (Ülman, 1961b, s.72).

Türkiye-SSCB arasında II. Dünya Savaşı sonrasında ortaya çıan çatışma hali, Türkiye-ABD ilişkilerini işbirliği sürecine döndüren temel etmen olmuştur. Özellikle ABD'nin bu dönemde infiratçılık politikasından vazgeçmesi, SSCB ile ABD’nin Avrupa, Ortadoğu, Akdeniz, Balkanlar, Kafkasya konularında karşı karşıya gelmelerine sebep olmuştur. Bu durum Türkiye'nin ABD nezdindeki konumunu güçlendirmiş, Türkiye$\mathrm{ABD}$ iş birliği sürecini tetiklemiştir. Bu işbirliğinin diğer etken ülkesi İngiltere olmuştur. ABD ve Türkiye için önemli bir müttefik sayılan İngiltere'nin savaştan sonra zayıflaması, savaş içerisinde ve savaş sonrasında Yunanistan ile birlikte Türkiye'ye artık daha fazla yardım edemeyeceğini ABD Büyükelçiliği vasıtasıyla ileten İngiltere (Truman Library J.M. Jones Papers, March 3, 1947) ABD'nin her iki ülkeye de yardım etmesi gerektiğini söylemiştir.

ABD ile Türkiye arasında Missouri zırhlısının ziyareti ile başlayan yakınlaşma, İngiltere'nin desteği ile ekonomik temelde yeni bir iş birliğine dönüşmüştür. Daha önce 'Ödünç Verme ve Kiralama Yasası' kapsamında Türkiye' nin aldığı borçların tamamını silen $\mathrm{ABD}$, resmileşen işbirliği sürecini Truman Doktrini ile ilan etmiştir. Sovyetlerin Ortadoğu Bölgesi'nde yapacakları bir müdahalenin etkisinden çekinen Başkan Truman ilgili kurumların desteğini aldıktan sonra, 12 Mart 1947 tarihinde meclis oturumunda sunduğu bir mesajla Yunanistan ve Türkiye'den bahsetmiştir. 
Truman, Kongre'den Yunanistan ve Türkiye'ye 400 milyon dolarlık askeri yardım yapılması için kendisine yetki verilmesini istemiş; Amerikan Kongresi, 22 Mayıs'ta Yunanistan'a 300 milyon, Türkiye'ye ise 100 milyon dolarlık askeri yardım verilmesini kabul etmiştir (Armaoğlu, 2005, s.441442).

Soğuk Savaş tarihi için oldukça önemli bir dönüm noktası sayılan Truman Doktrini, Türk dış politikasının SSCB karşısında 1945'ten itibaren yaşadığı milli güvenlik tehlikesi karşısında rahat bir nefes almasını sağlamıştır (Gözen, 2012b, s. 390). Truman Doktrini ve daha sonra Marshall Planı ekonomik yardım olmaktan daha çok Türkiye'nin Sovyet Rusya karşısında Batı'nın özellikle de ABD'nin desteğini aldığının işaretiydi. Bu doğrultuda Türk-Amerikan ilişkileri Truman Doktrini ile işbirliği sürecinde oldukça önemli bir atılım sağlamıştır. 1947 yılında Truman Doktrini ile başlayan kesintisiz işbirliği süreci, Türkiye'nin 1952 yılında ABD'nin önderliğinde askeri işbirliği örgütü olarak kurulan NATO'ya (Sander, 1996, s.237-238) üç yıllık gecikmeyle de olsa dâhil olması, işbirliği sürecinin zirve noktasını teşkil etmiştir.

\subsubsection{0 - 1960 Döneminde Türk Amerikan İlişkileri}

1949 yılında kurulan NATO'ya Türkiye'nin üye olmamış olması, Türkiye kamuoyunda dış politikada başarısızlık olarak değerlendirilmiştir (Erhan, 2004, s. 545). Özellikle bu konuda SSCB'ye karşı Truman Doktrini ile iyi bir seviyeye gelen Türk-Amerikan ilişkileri Türkiye için kritik bir tartışma meydana getirmiştir. Türkiye'nin NATO'ye üye olamamasıyla birlikte iki endişe belirmiştir. Bunlardan ilki ittifak garantisi verilmemiş olan Türkiye'nin yeni bir Sovyet tehdidi karşısında, güvenliğinin nasıl korunacağıdı. İkinci ise Türkiye'nin Truman Doktrini'yle aldığı maddi yardımın NATO ittifakı ile kesintiye uğrayıp uğramaması meselesiydi (Gönlübol ve Ülman, 1996, s.225).

Türkiye'nin NATO'ya üye olmaması milli güvenlik açısından ciddi bir tehlike olarak belirmişse de Türkiye'nin 1952 yılında NATO'ya üye olması, Türkiye'nin endişelerinden daha çok $\mathrm{ABD}^{\prime}$ nin küresel siyasetinden kaynaklanmıştır. SSCB'nin artan nükleer gücü karşısında, ABD'nin olası bir savaş durumunda Moskova'ya cevap vermesi için SSCB'ye yakın yerlerde hava üssüne ihtiyacı vardı. ABD bu amaçla Türkiye'den kullanmak 
üzere üs istemiş, fakat Türkiye'nin NATO üyeliği gerçekleşmeden bu isteğin yerine getirilemeyeceğini bildirmiştir. SSCB'nin tüm dünyada yayılma emeli göstermesi, Yugoslavya'nın 1948 yılında Balkanlar ve Orta Avrupa'da ortaya çıkardığı tehlike, ABD için NATO'nun güney kanad1nın güçlendirilmesi için Türkiye ve Yunanistan'ın üyeliği fikrini ortaya ç1karmıştır. Diğer taraftan Türkiye'nin NATO ve daha da önemlisi ABD için Kore Savaşı'nda ortaya koyduğu fedakârlık, üyelik sürecini hızlandıran bir diğer etmen olmuştur. Tüm bu gelişmeler karşısında Türkiye, 18 Şubat 1952 tarihinde NATO'ya üye olmuştur (Erhan, 2004, s.548-550). Fahir Armaoğlu'na (1999, 424-425) göre "Tam İttifak" olarak adlandırılan bu dönemde, Türkiye; "koyu bir Amerikan politikası izleyerek ve Amerika'nın dümen suyunu hiç bırakmayarak" ikili ilişkileri sürdürmüştür. Uzun vadede bu politikanın Türkiye'nin bir takım askeri üs ve tesisleri ABD'nin kullanımına sunması ve bu tesislerde yer alan ABD'li personele adli yetkilerin tevdi edilmesi gibi sonuçları ortaya çıkmıştır.

$\mathrm{Bu}$ dönemin dış politikası Demokrat Partili çevreler tarafından dinamik ve çok boyutlu bir dış politika olarak tanımlanmış ve bunun bilinçli bir tercih olduğu ifade edilmiştir (Çelik, 2015, s.83.). Dwight D. Eisenhower'ın 1952' de Amerikan başkanı olması ile Ortadoğu'daki Türk-Amerikan ilişkileri de yeni bir safhaya girmiştir. Eisenhower'ın 1953 yılında yürürlüğe koyduğu 'Yeni Bakış Stratejisi' Sovyetler Birliği'nin çevrelenmesi amaciyla, Ortadoğu ve Asya-Pasifik bölgelerinde yeni ittifakların kurulmasını öngörmekteydi. Türkiye'nin NATO'ya üye olmasıyla siyasal, ekonomik açılardan sonra askeri açıdan da gelişerek tekâmül eden ilişkiler Eisenhower'ın 'çevreleme' stratejisinde Türkiye'ye önemli bir rol biçmesine imkân tanımıştır. Bu dönemde Türkiye'nin öncülüğünde Ortadoğu'da Bağdat Paktı kurulmuştur. İngiltere, Pakistan, İran kısa süre içerisinde anlaşmaya taraf olsalar da ABD; İsrail, Misır ve Suudi Arabistan'ın yoğun tepkisinden çekinerek sadece gözlemci statüsü ile katılmıştır. Pakt diğer Arap devletlerin üyeliğini hedeflemişse de beklenenin aksine hiçbir Arap ülkesinin desteğini sağlayamamıştır. 1958 yılında Bağdat'ta meydana gelen darbe sonrası Irak'ın Pakt'tan çekilmesiyle, Pakt'ın etkinliğini iyice azaltmış ve örgütün ismi 21 Ağustos 1959'da CENTO olarak değiş̧miştir. Bölge ülkelerinin bütün olumsuz tepkilerine rağmen Türkiye, bu dönemde ABD'nin Ortadoğu'daki planlarının önemli bir oyuncusu ol- 
muştur (Bozdağlıoğlu, 2012, s.468-469). Türkiye'nin ABD'nin öncülüğünde dâhil olduğu 'çevreleme' stratejisi, Türkiye-ABD ilişkilerini geliştiren önemli bir etmen olmakla birlikte, bu durum Türk dış politikası için oldukça zararlı olmuştur. Türkiye, Bağdat Paktı sebebiyle, Batının bir askeri uzantısı olarak algılanmış ve Arap dünyası tarafından sürekli olarak suçlanmıştır. Bu durum ise Türkiye'nin ABD ile ilişkilerinin işbirliğinden çatışma sürecine döndüğü anlarda manevra kabiliyetini kaybettirmiş, Türkiye, bölge ülkelerinden istediği desteği alamamıştır (Sezer, 1999, s.450).

Demokrat Parti İktidarı boyunca iyi bir seyir yakalayan Türk-Amerikan ilişkileri, Kore Savaşı, NATO üyeliği, Bağdat Paktı, CENTO gibi girişimlerle işbirliği sürecini oldukça önemli bir noktaya taşımıştır. Karşılıklı olarak atılan adımların neticesinde Türkiye batı kulübünün bir üyesi olarak Sovyet tehdidine karşı aradığı desteği sağlarken, ABD ise Türkiye'nin jeopolitik konumu sayesinde bölgede istediği adımları atmış, olası bir nükleer savaşta Sovyetlere erken müdahale edebilmek için Türkiye'de askeri üslere sahip olmuştur. Demokrat Parti Hükümetleri döneminde ABD ile yürütülen ilişki, 27 Mayıs 1960 askeri darbesiyle farklı bir seyir yakalamıştır. 27 Mayıs darbesiyle DP İktidarına son verilirken, askeri idarenin dış politika çizgisinin nasıl olacağı en çok merak edilen konu olmuştur. Askeri idare 27 Mayıs 1960 sabahı radyoda yayınladığı bildiride, NATO ve CENTO'ya bağlı olduğunu bildirmiştir. Askeri idarenin ABD'ye yönelik ikinci önemli hamlesi ise batı ile her zaman yakın ilişkiler içerisinde olmuş olan Selim Sarper'i dışişleri bakanlığı görevine getirmek olmuştur. Türk dış politikasında ara dönem olarak nitelendirilebilecek olan on beş aylık darbe süreci boyunca, Türk-Amerikan ilişkilerinde önemli bir değişim yaşanmamış mevcut işbirliği sürdürülmüştür. ABD, Türkiye'ye yaptığ1 yardımı kesmeden sürdürmüştür. Bu dönemde Türkiye, aldığı dış yardımın \% 75'ini ABD'den almıştır (Aknur, 2012, s.549-552).

\subsubsection{Türk-Amerikan İlişkilerinde İşbirliğinden Gerilemeye: 1960-1990}

Türkiye ile ABD arasında komşuluk ilişkilerine dayanan herhangi bir tarihsel, kültürel bağ olmaması, iki devlet arasındaki münasebetleri şartların getirisi olarak geliştirmiştir. II. Dünya Savaşı sonrasında SSCB’nin bir heyula olarak Avrupa, Asya ve özellikle Ortadoğu için belirmesi, Türk- 
Amerikan ilişkilerini geliştiren temel etkendi. 1960 yılından itibaren ABD -SSCB arasında başlayan "Yumuşama/Detant", Türkiye'nin ABD ile olan durumunu da etkilemiştir. Bu süreç her ne kadar eninde sonunda gerçekleşecekse de ABD'nin 'Detant' döneminde Küba Füze Krizi başta olmak üzere giriştiği bazı eylemler, Türkiye tarafından Amerika'nın sorgulanmasına neden olmuş, Türk-Amerikan ilişkilerinde işbirliğinden gerilemeye hatta çatışmaya doğru giden bir sürece girilmiştir.

ABD-Türkiye ilişkilerindeki ilk derin kırılma Küba Krizinde yaşanmıştır. ABD, Detant dönemi rüzgarı ile SSCB ile daha az sorunlu ilişkiler yaşamaya, tehdit dilini daha az kullanmaya başlamıştır. Karşılıklı iki aktör arası yumuşak tutum, aktörler arasında bazı konularda uzlaşmayla sonuçlanmıştır. Bu bağlamda ABD, Türkiye'ye bilgi vermeden, Türkiye'yi Füze kalkanı kapsamı dışında tutmuştur. Türkiye bu haliyle Sovyet tehdidine açık hale gelmiştir. Bu tutum ise Türkiye'de adeta ABD'ye karşı hayal kırıklığı meydana getirmiştir. İlerleyen dönemlerde Kıbrıs meselesinde, Yunanistan ile ilişkilerde de Türkiye yalnız bırakılmış, hatta ABD tarafından tehdit dili kullanılarak ötekileştirilmiştir.

Detant ya da yumuşamayı ABD ve Sovyet blokları arasında karşılıklı savaş tehlikesinin azalması ve komünist ile antikomünist devletlerarasında siyasal, ekonomik, kültürel ve teknolojik anlaşmaların sayılarındaki artış olarak tanımlamak mümkündür (Sander, 1996, s.399). Bloklar arasında yaşanan bu yumuşamanın gerçekleşmesinde ABD ile SSCB' nin 1962 yılında yaşadıkları Küba Krizi oldukça etkin olmuştur. İki ülkenin Küba' da bir savaşın eşiğinden dönmeleri, iki blok arasında önemli bir k1rılma meydana getirerek aralarındaki çatışmalara daha farklı bir bakış açısıyla bakmalarını sağlamıştır (Armaoğlu, 2005, s.608-611).

Türkiye-ABD ilişkilerini işbirliği seviyesine çıkaran küresel ve bölgesel gelişmeler, 1960'lı yıllarda Türkiye'nin ABD'den bağımsız yürütmeye çalıştığ bazı bölgesel politikalar, Türk-Amerikan ilişkilerini düzenli bir biçimde ilerleyen işbirliği sürecinden dalgalı bir şekle dönüşen yapıya dönüştürmüştür. Türkiye'nin detant döneminde, $\mathrm{ABD}$ 'nin tahakkümünden sıyrılarak bağımsız olarak sürdürmek istediği milli politikası olan Kıbrıs meselesi, 1964 ve 1974 yıllarında Türkiye-ABD ilişkilerinin iki kez kırılma yaşamasına neden olmuştur.

Zürih ve Londra Anlaşmaları sonrasında bağımsız hale gelen Kıbrıs'ta kısa süre içerisinde olayların tırmandığı görülmüştür. Kıbrıslı Rumların 
'Enosis' görüşlerini, bağımsızlık sonrası da sürdürmeleri Kıbrıs'ta kısa süre içerisinde gerilimi tırmandırmıştır. Yönetim, temsiliyet konularında yaşanan çatışmalar kısa süre içerisinde, 1963 yılında Enosis taraftarı Rumların Türklere saldırmasına varan bir takım olayları ortaya çıkarmıştır. Tarihe 'Kanlı Noel' olarak geçen Rum saldırıları neticesinde 364 Türk katledilmiş, 25 bin Türk ise göç etmek durumunda kalmıştır (Arık, 2011, s.6).

Olayların durmaması ve Kıbrıs Cumhurbaşkanı Makarios'un tansiyonu yükselten girişimlerde bulunması, Türkiye'nin Kıbrıs'a müdahalesi kararını kesinleştirmiştir. 7 Haziran'da Türk askerinin Kıbrıs'a çıkartılması planlanmış, fakat tarihe Johnson Mektubu olarak geçen, ABD Başkanı Johnson'un Başbakan İsmet İnönü'ye gönderdiği 'ifadesi ağır tehdit dolu mektup' Türkiye'nin Kıbrıs'a asker çıkarmasını engellemiştir (Armaoğlu, 2005, s.788). Johnson'un mektubu o günkü şartlar içerisinde kamuoyu ile paylaşılamamış ancak 10 Haziran gününde İnönü'nün Johnson'a cevap verdiği yazılmıştır (Feridunoğlu, 2017, s.384). Johnson'un mektubunun Türk kamuoyu ile paylaşılması veya 'sızdırılması' ancak 1966 yılının Ocak ayında gerçekleşmiştir (Armaoğlu, 2005, s. 788).

Türkiye, Kıbrıs'ta yaşananlar karşısında meşru olmayan rejimin yerleşmesine izin vermemek ve Türkleri artan şiddet olaylarından kurtarmak üzere, müdahale kararı alarak (Ünlü, 2012, s.681-682) 20 Temmuz 1974 ve 16 Ağustos 1974 iki kez olmak üzere Garanti Anlaşması'na dayanarak Kıbrıs'a meşru bir müdahalede bulunmuştur (Sönmezoğlu, 2006, s.290291). Türkiye'nin Kıbrıs'a gerçekleştirdiği müdahalenin ikinci aşaması Batı'da özellikle de ABD'de kaygı meydana getirmiştir. ABD, ihtiyatlı bir tutum içinde görünmekle birlikte Amerikan kamuoyunda ve Kongre'de Türkiye aleyhinde bir hava meydana gelmiştir. Bu hava içinde ABD Kongresi, Türkiye'ye verilen silahların amaçları dışında kullanıldığı gerekçesiyle ambargo uygulanmasına karar vermiştir. ABD'nin aldığı ambargo kararı Türkiye'nin politikalarında iki unsuru ortaya çıarmıştır. Bunlardan ilki Türkiye, 1978'ten itibaren milli silah sanayisini geliştirmeye başlamasıdır. İkinci olarak ise dönemin Başbakanı Bülent Ecevit'in 1978 y1lında SSCB'yi ziyaret ederek SSCB ile 'Siyasi Belge' imzalamasıdır. Bu belge çok önemli bir vaat ya da işbirliği sunmuyorsa da NATO çevresinde anlaşmanın imzalanmış olması yeterli derecede bir endişe meydana getirmiştir. Türkiye'nin ambargonun kalkması için Kıbrıs konusunda aynı yıl aldığı taviz kararı ve ABD Başkanı Carter'ın girişimleri neticesinde 26 
Temmuz 1978 tarihinde ambargo kararı kaldırılmıştır (Gönlübol ve Kürkçüoğlu, 1996, s.589-592).

Türk-Amerikan ilişkilerini 1970'li yıllarda etkileyen diğer bir olay ise Haşhaş Sorunu olmuştur. Haşhaş Sorunu ABD'nin Türkiye'nin egemenlik haklarına müdahalesi sebebiyle kamuoyunda en az Kıbrıs kadar önemli bir sorun olmuştur. Üstelik Haşhaş Sorunu aynı zamanda ekonomik bir veçheye sahip olması sebebiyle kamuoyu tarafından daha dikkatle takip edilmiştir. Sorunun kökeninde, II. Dünya Savaşı́ndan sonra ABD'de uyuşturucu maddelerin kullanımında artış yaşanması yer almıştır. 1960'lı yıllarda çocukların uyuşturucu sebebiyle ölmesi üzerine kamuoyu baskısı altında kalan ABD yönetimi, dikkatini uyuşturucu üretiminde kullanılan haşhaş bitkisinin yetiştirildiği ülkelere yöneltmiştir. 1961 yılında gerçekleştirilen BM Uyuşturucu Üreten Ülkeler toplantısında “Tek Elden Üretim Antlaşması" imzalanmış, Türkiye bu anlaşmaya 1967 yılında taraf olarak haşhaş üretimini izne bağlayarak kısıtlamıştır. ABD'nin sürekli artan baskıları sonucunda 12 Mart 1971 sonrası göreve gelen Nihat Erim hükümeti tarafından ise tamamen yasaklanmıştır. Bu yasaklama nedeniyle ABD'nin Türkiye'ye ödemesi gereken tazminat ve mali destekler kısmen gerçekleştirilmiş ancak etkili sonuç alınamamıştır. 1974 yılına gelindiğinde ülkenin kendi ihtiyacı olan tıbbi amaçlı afyonun üretilememesi sorunlara neden olmuştur (Babahanoğlu ve Örselli, 2016, s.99-100; Erhan, 2004, s.701-703). 1973 seçimlerinden sonra Hükümet kuran Bülent Ecevit, 1 Temmuz 1974'te yasağın ABD'deki uyuşturucu sorununa çare olmadığını, buna karşı Türk çiftçisinin durumunu zora soktuğunu ifade ederek haşhaş ekimine izin vermiştir. Amerikan yönetimi karar sonrası, Türkiye'nin etkili önlemler almaması karşısında ekonomik ve askeri yardımın kesilmesini öngören bir dizi yasal kararlar almıştır. Türkiye'nin Kıbrıs'a müdahale ettiği aynı günlerde, Türkiye'ye ambargo uygulanması gündeme geldiğinde, haşhaş üretiminden memnun olmayan kongre üyeleri, ambargoya destek vererek Türkiye'yi cezalandırmak istemişlerdir (Uslu, 2012, s. 694).

ABD ile ilişkiler Turgut Özal tarafından sivil hükümetin kurulmasıyla birlikte kesintiye uğramamış aksine gelişerek sürmüştür. Bu doğrultuda 1982 yılında NATO manevraları Türkiye'de yapılmış, Wohlstetter Doktrini'nin uygulaması olarak Kasım 1982'de Doğu Anadolu'ya havaalanları inşa edilmeye başlanmıştır. Bunların haricinde uluslararası siyasette Tür- 
kiye, ABD'nin yanında daha fazla yer alırken aynı desteği ABD'den görememiştir. ABD'nin 1989'da Panama'yı işgali BM'de büyük çoğunlukla k1nanırken Türkiye, ABD lehinde oy kullanmıştır. Oysa ABD Türkiye'nin desteğiyle 1983 yılında kurulan Kuzey Kıbrıs Türk Cumhuriyeti'ni (KKTC) kınamış, KKTC'yi tanımak isteyen Pakistan ve Bangladeş'i vazgeçirmiştir. Bunun yanı sıra ABD, Eylül 1984'te 24 Nisan'1 “İnsanın insana hunharlık günü" ilan ederek Türkiye aleyhinde çalışan Ermeni lobisine büyük bir avantaj sağlamıştır. Bu dönemde Türkiye ABD'ye yalnızca iki konuda hayır diyebilmiştir. Bunlardan ilki Cruise ve Pershing füzeleri konusunda 1985'te ek nükleer yükümlülük almayı reddetmesidir. İkincisi ise Ermeni tasarısı Senato gündeminde düşene kadar ABD uçuşlarını engellemesi ve 6. Filo'nun ziyaret isteğini geri çevirmesidir (Oran, 2002, s.30$31)$.

Soğuk Savaş'ın son evresinde Türkiye-ABD ilişkileri, bir önceki döneme kıyasla daha iyi bir iyi seviye yakalamışsa da yine inişli çıkışlı bir seyir takip etmiştir. Kıbrıs meselesi, Ermeni sorunu, maddi sıkıntılar gibi konular Türkiye'nin istediği şekilde gelişmiyordu. Bu dönemde Türkiye için Özal'lı yıllarla birlikte ABD ile hareketli bir dış politika izlenmiştir. 1980'li yıllar sonra ererken Türkiye, kırmızıçizgisi sayılabilecek konularda ABD'den hiçbir destek sağlayamamıştır. Fakat ABD yine de Türkiye için müttefik olma halini muhafaza etmiş, 1990'l1 yıllar boyunca sürdürülen müttefiklik yapısı için daha da önemli hale gelmiştir (Çelebi, 2012, s.762763).

\subsection{Soğuk Savaş Sonrası Türk-Amerikan İlişkileri: Yeniden İşbirliği Süreci}

1990'lı yıllarla birlikte Türkiye-ABD ilişkilerinde mezkûr uluslararası gelişmelerin bir sonucu olarak Avrupa-Balkanlar, Kafkasya-Orta Asya ve Ortadoğu gibi yeni işbirliği alanları ortaya çıkmıştır. Bu doğrultuda TürkAmerikan ilişkileri 90'lı yıllarda belirleyen temel yapı her iki ülkenin dış politikasındaki bu ortak alanlarla ilgili atılan adımlar olmuştur. Bu doğrultuda Körfez Savaşı gerek ABD’nin uluslararası arenada tek süper güç olduğunu ilan etmesi açısından gerekse Türk-Amerikan ilişkilerinde olduğu gibi iki ülkeyi yakınlaştırması açısından oldukça önemli bir milat sayılmaktadır. Saddam Hüseyin yönetimindeki Irak'ın Kuveyt'i işgal et- 
mesi sonrasında ABD'nin Irak'a müdahale etmesinde Türkiye, aktif olarak ABD'nin yanında yer alarak Türk-Amerikan ilişkilerini ittifak ilişkisi içerisinde sürdürmüşlerdir. Türkiye, Körfez krizi sırasında ABD'ye üç konuda yardımcı olmuştur; hava sahasını kullandırmak, Irak sınırına asker kaydırarak müttefiklere yardım etmek ve son olarak Suudi Arabistan'da toplanan müttefik kuvvetlerine birlik göndermek. Türkiye, verdiği destekle ABD'nin yardımını ummuşsa da savaşın maddi külfeti ve Türkiye'nin beklentileri ABD tarafından giderilmemiş, üstelik Irak sorunu sonraki yıllarda da Türkiye için problem olmaya devam etmiştir. Fakat Türkiye, Körfez Savaşı'nın devamı niteliğinde sayılabilecek olan "Çekiç Güç" yapısına destek sağlayarak, Körfez savaşından kaynaklanan zararlarını tazmin edemediği gibi ABD'yi karşısına almamak ve bölgesel politikalarını sürdürmek için işbirliği sürecini askeri seviyede sürdürmeye devam etmiştir (Uzgel, 2002, s.255, 263).

Çekiç Güç'ün devam etmesi ve Türkiye'nin bu askeri yapıya ev sahipliği yapması, Türkiye'nin izlediği dış politikanın iç politikada eleştirilmesine neden olmuştur. 90'll yıllar boyunca süren eleştiri ve Türkiye-ABD arasında süren gerilimli bir konu olan Kuzey Irak'taki Kürt yapılanmaları ve bunların birbirleriyle olan ilişkisi, Türkiye-ABD ilişkilerinde önemli bir faktör olarak 1999 yılına kadar sürmüştür. Türkiye ile ABD arasında 1998 yılında Irak'taki Kürtlerin durumu ile ilgili uzlaşma, ABD Merkezi Haber Alma Teşkilatı (CIA) ve Dışişleri Bakanlığı'nın PKK terör örgütü lideri Abdullah Öcalan'ın yakalanmasında Türkiye'ye yaptığı yardımla pekişmiştir (Hale, 2003, s.239-242). Türk dış politikası ve milli güvenliği için oldukça önemli olan PKK meselesinin ABD'nin yardımıla -kısmen1999 'da çözülmesi, Türk-Amerikan ilişkilerinde çatışma barındıran bir alanın sona ermesini sağlamıştır.

Soğuk Savaş'ın sona ermesi sonrasında Türk-Amerikan ilişkilerinde yeniden başlayan yakınlaşma Ortadoğu eksenli olarak sürmüştür. TürkAmerikan ilişkilerinin 1990'lı yıllarda bir diğer işbirliği alanı ise Balkanlar olmuştur. ABD ve Türkiye, Yugoslavya'nın dağılması sonrasında yaşanan Bosna'daki çatışmalarda işbirliği yapmışlardır. Her iki ülke yalnızca Balkanlardaki askeri işbirliği çerçevesinde değil, diplomatik, insani müdahale ve bölgesel işbirliği örgütlenmesi konularında da işbirliği yapmışlardır. Türkiye ve ABD Mart 1994'te gerçekleştirilen Boşnak-Hırvat Federas- 
yonu konusunda da birlikte hareket etmişlerdir. ABD'nin girişimleri neticesinde imzalanan Dayton Anlaşması sonrasında iki ülke arasındaki işbirliği sürmüştür. Türkiye, bölge barışı için oluşturulan BM gücüne asker yollayarak yardımda bulunmuştur. Türkiye ile ABD arasındaki bir başka işbirliği alanı 1998 Kosova olaylarıdır. ABD'nin askeri faaliyetleri yanında, Türkiye de bölgeye savaş uçağı göndererek; gözleme, koruma ve görev uçuşlarında rol almıştır. Ayrıca ABD'nin kullanımı için Çorlu ve Bandırma üslerinin kullanımına müsaade edilmişse de anlaşmanın yapılması üzerine üslerin kullanımına gerek kalmamıştır (Uzgel, 2002, s. 276277).

\subsection{1- 2018 Arası Dönem}

Türk-Amerikan ilişkilerini 2000'li yıllarda iki dönem halinde izlemek mümkündür, birinci dönem işbirliğinin sürdüğü dönemdir. İkinci dönem ise Türk-Amerikan İlişkilerinin Türkiye'nin iç dinamiklerinden ve ABD'nin politikalarından kaynaklanan yapı sebebiyle kırılmaların yaşandığı ve bu kırılmaların çatışmaya döndüğü dönemdir.

Türk-Amerikan ilişkilerinde işbirliği dönemi 11 Eylül saldırıları sonrasinda atarak devam etmiştir. ABD Başkanı George W. Bush'un 11 Eylül saldırıları sonrası 2002 yılında açıkladığı ‘Bizimle değilseniz, bize karşısınız' düsturu, Türk-Amerikan ilişkilerini terörizm ve terörle mücadele söylemleri etrafında şekillendirmiştir. 11 Eylül saldırılarının ilk neticesi, ABD'nin Afganistan'a saldırması olmuştur. Türkiye, ABD'nin Afganistan'a müdahalesi sırasında ABD'nin 'uluslararası terörizme' karşı birlikte hareket etme isteği doğrultusunda hava sahasını kullanımına açarak müdahalede ABD'nin yanında yer almıştır. Kasım 2003'te Başkan Bush Ortadoğu'da reformları teşvik etmek amacıyla büyük bir proje başlatacağını ilan etmiştir. Büyük Ortadoğu projesi doğrultusunda ABD, Irak'a müdahale için Türkiye'den destek beklemiştir. TBMM'de 1 Mart 2003 tarihinde gerçekleşen oylamada ABD'ye Türk topraklarını kullanma ve Türk askerinin yurt dişında gönderilmesine izin veren tezkere reddedilmiştir. $A B D$ nin beklemediği bir netice alması iki ülke ilişkileri üzerinde gerginliği doruk noktasına çıkartmıştır. ABD dışişleri bakanı Colin Powell, Clinton'un Türk-Amerikan İlişkilerini tanımlamak için kullandığ 1 "stratejik ortaklık" kavramanı kullanmamaya başlamıştır (Keyvan, 2011, s. 104,107). 
Çağrı Erhan'a (2010, s. 84) göre, Türkiye ile ABD arasında ne önceden ne de daha sonra bir stratejik ittifak olmamıştır. Türkiye ile ABD arasında bir stratejik ittifaktan bahsedebilmek için iki ülke arasında hiçbir üçüncü ülkeyle olmadığı kadar yüksek askeri ve ekonomik işbirliği gerekmektedir. $\mathrm{Bu}$ iki şart dışında ise her iki ülke kamuoyunun birbiri aleyhine olumsuz hissiyat beslememeleri ve her iki ülkenin küresel ve bölgesel gelişmeler bağlamında örtüşen bakış açısına sahip olmaları gerekmektedir. Mezkûr dört şart doğrultusunda, ABD'nin gerçek anlamda stratejik müttefiki sadece İngiltere ve İsrail'dir.

1 Mart 2003 tarihli Irak'a Türk askeri gönderilmesine dair tezkerenin reddedilmesi ile başlayan süreçte Türk Amerikan İlişkileri ciddi bir gerileme yaşamıştır. Tezkereyi izleyen dönemde, Çuval Krizi olarak da bilinen 4 Temmuz 2003'te Süleymaniye'deki 11 Türk subayının ABD tarafından tutuklanması hadisesi iki ülkeyi karşı karşıya getirmiştir (Akbaş, 2011, s.293). Bu olaylar iki ülke arasında çıar çatışmasına neden olarak ilişkileri iyice bozmuştur. İlişkilerin onarılması süreci ise ancak 2007 yılından itibaren aşama kaydetmiştir.

George W. Bush, başkanlığı Barack Obama'ya devrettiğinde TürkAmerikan ilişkileri 1 Mart krizi sonrası ciddi bir dizi problemler yumağına sahipti. Türk-Amerikan ilişkilerinde yaşanan gerginlik Türk kamuoyunda olumsuz yansıma bulmuştur. Bu durum 'değişim' sloganıyla 2008 yılında başkan seçilen Barack Obama döneminde bir umut olmuştur. Değişim Türk-Amerikan ilişkilerini normalleştirmek için önemli bir fursat olarak kabul edilmiştir. Bu doğrultuda Obama'nın ilk denizaşırı seyahatlerinden birini Türkiye'ye gerçekleştirmesi önemli bir işaret olarak değerlendirilmiştir (Keyvan, 2011, s. 105-106). Obama'nın Türkiye gezisi sırasında 6 Nisan 2009 tarihinde TBMM'de bir konuşma gerçekleştirerek; iki ülke arasındaki ilişkileri yeniden canlandırmaktan, İslam ile bir savaş içerisinde olmadıklarından bahsetmiş ve ABD'nin Türkiye'nin $\mathrm{AB}$ üyeliğini desteklediğini, Irak'ın toprak bütünlüğü ve PKK konusunda Türkiye'nin yanında yer alacağını ifade etmiştir. Obama, aynı gün gerçekleşen basın toplantısında ise iki ülke ilişkilerini "model ortaklık" olarak nitelendirmiştir (Sönmezoğlu, 2016, s. 500, 508). Bush dönemine kiyasla Obama'nın liderliğinde -NATO-AB Füze Kalkan projesi örneğinde olduğu gibi- ABD'nin, Türkiye ve $A B$ ile münasebetleri daha fazla işbirliği arayışı içerisinde olmuştur (Aydın, 2019, s.719-735). 
Başkan Bush döneminde Türk-Amerikan ilişkilerinde yaşanan çatışma, Obama'nın seçilmesi ile birlikte yerini ‘Model Ortaklık' temelinde ilişkilerin tamirine yönelik beklentiye bıraksa da Obama'nın ikinci başkanlık döneminin yaşanmasıyla birlikte iki ülke arasında bölgesel problemler üzerinde ciddi anlaşmazlıklar yaşanmaya başlamıştır. 'Model Ortaklık' iddiası ise söylemden öteye geçememiştir. Arap Baharı sonrasında Misır'da 2013 yılında Sisi'nin darbe yaparak Mursi yönetimini görevden uzaklaştırması, Türk-Amerikan bakışının farklılaştıran önemli bir etken olmuştur. Mısır'dan sonra Suriye' de ortaya çıkan uyuşmazlık, etkisini günümüze kadar sürdüren bir problem olarak ortada durmaktadır. Küresel ve bölgesel gelişmelerin dişında Türkiye'nin içeride yaşadığı bir takım olaylarda Türk-Amerikan ilişkileri bu süreçte etkilenmiştir. Bu olaylardan birisi olan Gezi Parkı Şiddet Eylemleri, Türk-Amerikan ilişkilerinde önemli bir diğer kırılma anı olmuştur. Gezi Parkı Şiddet Eylemleri sırasında ABD medya ve kamuoyunun Türk Hükümeti'ne karşı bir algı oluşturma çabası ilişkilerin giderek bozulmasına neden olmuştur. ABD'nin Türkiye'nin güvenlik kaygılarına karşı kayıtsız kalma durumu ve bunun yanında Türkiye'deki ciddi krizlere hızlı ve acil cevap vermede yaşanan başarısızlık sürmüştür. Bu doğrultuda ABD yönetimi, 15 Temmuz Darbe girişimine de kayıtsız kalmıs, bu durum ise ikili ilişkilerde önemli bir problem olmuştur. ABD yönetiminin 15 Temmuz Darbe Girişimi sonrasında konuyla ilgili yaptığı açılamalar için seçtiği kelimeler ve mesajların tonu bekle gör politikası izlediği algısını oluşturmuştur. Obama'nın 15 Temmuz Darbe Girişim sonrası Türk mevkidaşını aramak için dört gün beklemesi, darbe sonrasında yine FETÖ lideri Gülen'in Türkiye'ye iadesi konusunda aleyhte tutum takınılması, Türk-Amerikan ilişkileri tarihinin en kötü dönemlerinden birisinin yaşanmasına sebep olmuştur. Türkiye'nin FETÖ konusunda ABD'den beklediği desteği alamaması buna karşın Türkiye'nin kırmızı çizgisi olan Suriye konusunda DEAŞ bahanesiyle YPG/PKK'ya silah ve askeri mühimmat başta olmak üzere destek vermesi, ilişkileri ciddi bir çatışmaya dönüştürmüştür (Kanat v.d., 2017, s.8-10). Oysa Türkiye, DAEŞ başta olmak üzere Kuzey Suriye'de ortaya çıkan terör örgütlerini temizlemek üzere, birtakım girişimlerde bulunarak, uluslararası terörist yapı olarak adlandırılan DAEŞ’a karşı aktif bir faaliyet içerisine girmiştir. Türkiye, 2014 yılının sonunda Kobani'de 
DEAŞ'a karşı operasyona destek vermek üzere Irak Kürt Bölgesel Yönetimi'ne bağlı güçlerin kendi toprakları üzerinden Suriye'ye geçmesine izin vermiştir. Keza Türkiye'nin girişimleri ile DAEŞ’a karşı mücadele için 2015 yılında ABD ile Suriyeli Muhalifleri kapsayan eğit donat anlaşması imzalanmıştır. (Erdağ, 2017, s. 331-332) Türkiye'nin Suriye başta olmak üzere ABD'nin terörizmle mücadele konusunda ABD'nin yanında yer alırken Obama'nın ikinci başkanlık döneminde ABD yönetiminin Türkiye ile ilişkileri problemli bir zeminde ilerlemiştir.

Türk-Amerikan ilişkilerinin hızla uçuruma sürüklendiği 15 Temmuz sonrasındaki süreçte $\mathrm{ABD}$ 'de başkanlık seçimlerinin yenilenmesi, Obama'nın ikinci döneminde yaşanan tüm olumsuzlukların giderilmesi için olumlu bir firsat olarak belirmiştir. Donald Trump'un Ocak 2017'de göreve gelmesi FETÖ, PYD/PKK gibi Türkiye için milli güvenlik noktası sayılan konularda Trump'ın olumlu adım atacağı beklentisi, Türk-Amerikan ilişkileri için iyimser bir beklenti oluşturmuştur. Obama yönetiminin gerilim dolu sürecinden sonra Trump'ın seçilmesi sonrasında olumlu bir zeminde başlayan Türk-Amerikan ilişkileri kısa süre içerisinde beklentileri tersine çevirmiştir. ABD'nin Türkiye'nin iki temel beklentisi olan PYD/PKK ve FETÖ konularında beklenen adımları atmaması bu gelişmeyi etkileyen temel sebep olmuştur. Türkiye PYD/PKK konusunda hiçbir şey yapmayan ABD yönetimine rağmen Sincar'a operasyon düzenlemiştir. Türkiye, genelde Suriye özelde ise PYD/PKK konusunda kararlı olduğunu Suriye operasyonu ile göstermesine karşın Trump, Türkiye'yi dikkate almayarak 10 Mayıs 2017'de YPG'nin ABD tarafından doğrudan silahlandırılması için yetki vermiştir. Suriye politikasında Obama yönetiminden farklı bir irade ortaya koymayacağı mesajını veren Trump, bir taraftan da Türkiye ile görüşmeyi sürdürmeye devam etmiştir (İnat ve Caner, 2017, s.131-132).

Trump döneminde Obama'nın mirasını devam ettireceğinin en açık delili, Trump'ın Obama'nın DEAŞ’la Mücadele Özel Temsilcisi görevini yürüten Brett McGurk'un görevini devam ettirmesidir. McGurk, DEAŞ’la mücadele altında PYD/PKK'ya destek vermiş PKK'nın bir başka kolu olan YPG'nin sözcüsü Polat Can'dan plaket almıştı (Yeni Şafak, 20 Ocak 2017). Obama döneminde sık sık Kobani'yi ziyaret ederek terör örgütü ile görüşen McGurk, Türkiye'nin her defasında tepkisini çekmiş, Obama yönetimi ile ilişkilerin gerilmesine neden olmuştu (Türkiye, 21 Ocak 2017). Obama 
yönetiminde başlayan PYD/ PKK yakın ilişkileri Trump yönetiminde mevcut halini McGurk'un görevini devam ettirmesiyle sürmüş, bu durum ise Türk-Amerikan ilişkilerini gerilmesine neden olmuştur. McGurk d1şında DEAŞ’a karşı koalisyon sözcüsü ABD'li Albay Ryan Dillon PKK'nın uzantısı YPG/SDG'li teröristleri patlayıcılarla nasıl eğittiklerine ilişkin fotoğraflar paylaşarak Türkiye'ye rağmen ABD'nin PYD/ PKK'ya verdiği desteği gözler önüne sermekten çekinmemiştir (Ortadoğu, 1 Mart 2018).

Türkiye 2017 yllında ABD'nin tırlar dolusu silah ve mühimmat yardımı karşısında PYD/ PKK-ABD ittifakına karşı sesini yükseltmiştir. 2017 Haziran'ında Milli Güvenlik Kurulu sonrası yayınlanan bildiride “...Suriye Demokratik Güçleri kisvesi altında faaliyet gösteren PKK/PYD-YPG terör örgütüne uygulanan destek politikasının dostluk ve müttefiklikle bağdaşmayacağı..." bildirilerek ABD'ye açık bir mesaj verilmiştir (Star, 1 Haziran 2017). ABD'nin mevcut desteğini sürdürmesi, Türkiye'nin ABD'ye yönelik mesajlarının tonunu da gittikçe sertleştirmiştir. ABD'nin Obama yönetiminde başlayan terör örgütlerine eğitim ve silah ve mühimmat başta olmak üzere yardım sağlanması, Trump yönetiminde kesintiye uğramadan devam etmiştir. Oysa ABD, Türkiye'nin milli güvenliğini sağlamak adına gerçekleştirdiği Fırat Kalkanı, Zeytin Dalı gibi operasyonlara destek vermediği gibi bu operasyonları eleştirmiştir (Karar, 14 Şubat 2018).

15 Temmuz Darbe girişimi ile ilgili hazırlanan iddianamede ismi geçen ve hakkında 35 yıl hapis istenen İzmir Diriliş Kilisesi Rahibi Andrew Craig Brunson ABD - Türkiye ilişkilerinin Trump yönetimi döneminde geren bir diğer konu olmuştur. Brunson'un FETÖ ile bağlantılı olduğu, gizli tanıkların ifadeleri sonucunda ortaya çıkmış, Rahip tutuklanarak hapishaneye sevk edilmiştir. Brunson'un hakkındaki 'casusluk' iddialarının 15 Temmuz'la sınırlı kalmadığı, Gezi Parkı Şiddet Eylemleri, Suruç Saldırısı, Kobani Şiddet Olayları, Sur/Hendek Olayları gibi pek çok toplumsal olayda isminin planlayıcı olarak geçtiği görülmüştür. Brunson'un 15 Temmuz Darbe girişimi başta olmak üzere suçlanarak cezaevine gönderilmesi, kısa süre içerisinde Türk-Amerikan ilişkilerinde gerginleşen ilişkilerin çatışmaya dönmesine neden olmuştur. Trump yaptığı açıklamalarda Brunson'un serbest bırakılmasını talep etmiştir. Bu isteğin gerçekleşmemesi karşısında ise 2018'in yaz aylarında dolarda yaşanan yükselme, Türkiye tarafından ABD'yle irtibatlandırılmıştır. Doların TL karşısında yaşanan 
yükselişi, Türk kamuoyunda, ABD'nin Brunson'a karşı hamlesi olarak yürütülen dolar manipülasyonu şeklinde yorumlanmıştır. Finansal değişimlerle izah edilemeyecek kadar kısa sürede meydana gelen artış, Hazine ve Maliye Bakanı Berat Albayrak tarafından "Paramız doğrudan bir ABD Başkanı tarafından hedef alındı" diyerek ekonomik müdahalenin Trump tarafından gerçekleştirildiği ifade edilmiştir (Akşam, Ağustos 13, 2018). Trump'ın Brunson'la ilgili olmak üzere Türkiye aleyhinde sosyal medya üzerinden yaptığı paylaşımlar, Türkiye'ye kota uygulama kararı ve İçişleri ve Adalet Bakanlarına yönelik yaptırımlar, Türkiye'nin tepkisini çekmiş, Türkiye-ABD ilişkilerinde çatışma yaşanmasına sebep olmuştur.

Brunson'un serbest bırakılması, Türk-Amerikan ilişkilerine olumlu yansımışsa da ikili ilişkilerin bu süreçte ağır yara aldığı bir gerçektir. Özellikle Türkiye'deki dolar artışının ekonomi piyasalarında meydana getirdiği dalgalanma, Trump'ın Türk kamuoyundaki imajını olumsuz olarak etkilemiştir. Brunson sonrası ilişkilerde görece bir değişme gözlemlenmekle birlikte Türkiye'nin ABD'den bağımsız dış politika yürütmek istemesi ve hali hazırda sürmekte olan FETÖ, PYD/SDG/PKK, S-400 savunma sistemleri gibi konular Türk-Amerikan ilişkilerinin önünde büyük bir sorun yumağı olarak durmaktadır.

Trump döneminde ABD ve Türkiye arasındaki gerilim artarak devam etmiş, Türkiye için güvenlik tehdidi olan terör örgütlerine hem siyasi hem lojistik hem de mühimmat destekleri açıkça verilmeye başlanmıştır (Turaman ve Çelik, 2018, s.130).

Trump yönetiminin Suriye iç savaşındaki tutarsız politikaları bölgede istikrarsızlığı artırmaktadır. Trump'ın Suriye'nin Kuzeyine yönelik politikaları Türkiye ile ilişkilere zarar vermiştir (Akbaş v.d., 2018, s. 494). Benzer şekilde 2019 Ocak ayında Trump'ın Suriye'den çekileceklerini açıklamasından sonra, söz konusu çekilme takvimini Suriye'de Türkiye'ye karşı savaşan güçleri korumaya yönelik bir tutum içerisine girerek şekillendirmeye çalışması da Türkiye'de ABD yönetimine yönelik kuşkuları artırmiştır.

\section{Sonuç}

Bu çalışma yaklaşık iki yüzyıllık bir süreç gösteren Türk-Amerikan ilişki- 
lerini çatışma ve işbirliği sarmalında nasıl geliştiğini ve değiştiğini göstermeye çalışmaktadır. İlk kez 1800'li yıllarda Akdeniz'e gelerek ticaret yapmaya başlayan ABD ticaret gemileri, bu dönemde Osmanlı Devleti'ne bağlı Garp Ocaklarına vergi vererek Akdeniz'de ticaret tapmaya başlamıştır. Çok geçmeden iki ülke arasında imzalanan anlaşmalarla birlikte resmi hüviyet kazanan Osmanlı-ABD ilişkileri, yine bu dönemde çıkış eksenli bir seyir takip etse de şartların bir sonucu olarak istenilen seviyeye gelememiştir. I. Dünya Savaşı ile kesilen ilişkiler, Türkiye Cumhuriyeti'nin kurulmasından sonra ise hemen yeniden başlamamıştır. 1927' de yeniden başlayan Türk-Amerikan ilişkileri bu dönemde ittifak ilişkisi sayılamayacak bir seviyede olmuştur. II. Dünya Savaşı içerisinde kuvvetlenmeye başlayan ilişkiler, II. Dünya Savaşı sonrası ise İngiltere'nin yerini ABD'nin almasıyla birlikte ittifaka doğru ilerlemiştir. İki ülke arasındaki bu yakınlaşma ABD’nin Truman ve Marshall yardımları ile siyasi ve ekonomik seviyeye, Türkiye'nin 1952'de NATO'ya dâhil olması ile ise askeri seviyeye yükselmiştir.

Türkiye'nin 1952'de NATO'ya üye olmasıyla birlikte siyasi, ekonomik ve askeri bir ittifaka dönüşen Türk- Amerikan ilişkileri, Soğuk Savaş süresince Sovyetlerin faaliyetleri neticesinde şekillenmiştir. Özellikle Soğuk Savaş'ın 'Detante' döneminde ABD'nin çıkarlarını üstün tutması, Türkiye'nin feda edilebilirliğinin tartışılmasına neden olmuştur. 1964 sonrası Türk-Amerikan ilişkilerinin inişli çıkışlı bir seyir izlediği görülmüştür. 1960 yılında başlayan Kıbrıs sorunu 1974 yılında Türkiye'nin ABD’ye rağmen müdahale gerçekleştirmesi ile neticelenmiş, bu netice sonrası ise Türk-Amerikan ilişkileri yeni bir kopuş, çatışma yaşamıştır. 1980' de yaşanan dönüşüm Soğuk Savaş'in sonuna kadar Türk-Amerikan ilişkilerinde bir belirsizlik yaşanmasının önüne geçmiştir. 1983 yılında Turgut Özal'ın başbakanlığı ile başlayan değişim Türk-Amerikan ilişkilerine de yansıyarak çatışmadan işbirliğine evrilmiştir. Özal'ın yürüttüğü esnek diş politika, Soğuk Savaş'ın sona ermesinden sonra da devam etmiştir.

2000'li yıllarda ise AK Parti'nin iktidara gelmesiyle birlikte Türk - ABD ilişkilerinde yakınlaşma meydana gelmiş, ABD Irak'a 2003 yılında gerçekleştireceği operasyon için Türkiye'den yardım istemiştir. Tarihe 1 Mart Tezkeresi olarak geçen hadisede TBMM tarafından ABD'ye destek verilmesine hayır denmiştir. 1964, 1974 yıllarındaki kriz ve/veya çatışma dö- 
nemlerinde ABD'nin tahakkümü vardır. 1 Mart Tezkeresi'nde ise Türkiye'nin istediği olmuştur. Barack Obama'nın başkan olması ile birlikte Türkiye'de, Bush dönemi ABD politikalarından dönüş beklentisi oluşmuştur. Obama'nın ikinci döneminde bu beklentinin yerini gerilimin aldığı görülmüştür. Bu dönemde ABD ile Suriye, Mısır meselesi başta olmak üzere, bir takım çatışmalar yaşanmıştır. Özellikle ABD'nin DEAŞ bahanesiyle Suriye'de Türkiye'de terör eylemlerinde bulunan PKK/PYD'ye silah ve askeri mühimmat sağlaması, Gezi Parkı Olayları sırasında Türk Hükümeti aleyhinde bir pozisyon alması, 15 Temmuz Darbe Girişimi s1rasında ve sonrasında Türkiye'nin yanında yer almaması, Obama döneminde beklenen gelişmelerin gerçekleşmediğini göstermiştir. Türk-Amerikan ilişkileri çatışma eksenli kırılgan bir süreçte gelişme göstermiştir. Obama'dan sonra başkan olan Donald Trump, Türk-Amerikan ilişkileri için yeni bir beklenti oluşturmuştur. ABD'nin FETÖ Terör Örgütü firarileri için sığınak olması, Türkiye'nin tüm taleplerine rağmen ABD tarafından suçlu iadesi yapılmaması, ilişkilerin Trump döneminde de çatışma eğilimli olacağını göstermiştir. ABD’nin Trump döneminde tırlar dolusu silah ve mühimmatı YPG/PKK'ya sağlaması, Türkiye'nin güvenliği için Suriye' de yürüttüğü operasyonları stratejik ortağı olan ABD'nin desteklememesi iki ülke arasındaki çatışma sürecini beslemiştir. Trump döneminde Türk-Amerikan ilişkilerine sekte vuran bir diğer olay ise Rahip Brunson'un casusluk iddiasıyla gözaltına alınmasıdır. Brunson'un serbest bırakılması, Türk-Amerikan ilişkilerinde iyileşme beklentisini yükseltse de Türkiye ile ABD arasındaki S-400 Füze Sistemleri, YPG/PKK, Suriye, FETÖ konuları çatışma etkisini sürdürmektedir. Ayrıca henüz gündeme gelmeyen Ermeni Meselesi ile ABD'de tutuklu bulunan Halk Bankası yetkililerinin durumu da ilişkileri etkileyecek konulardandır. ABD kendi çkarları söz konusu olduğunda çıkarlarından Türkiye'nin zarar görmesi durumunda dahi vaz geçmemektedir. ABD'nin bu tutumu, iki aktör arası ilişkileri işbirliğinden çatışmaya doğru evirmektedir. ABD'nin ilkesel değerleri zaman zaman görmezden gelerek benimsediği tutumlar Türkiye'nin çıarlarına zarar vermektedir. Böyle durumlarda da iki ülke gündemini işbirliği unsurları değil çatışma unsurları belirlemektedir. Ancak tarihsel süreçten anlaşıldığı kadarıyla görünen odur ki iki ülke çatışsa da ilişkileri sona erdirme ya da büyük oranda kesme yönünde bir tutum içinde olmamaya özen göstermektedir. 


\title{
EXTENDED ABSTRACT
}

\section{Turkish-American Relations in the Second Century of Cooperation and Conflict Spiral}

\author{
Zafer Akbaş - Ahmet Hüsrev Çelik - Melih Duman \\ Düzce University - Aksaray University
}

Turkish-American relations, which goes back to the 20th century, began in the 19th century for the first time with the US ships coming to the Mediterranean in regards of trade paying taxes to the Garp Ocakları of the Ottoman State and continued uninterruptedly until today. In this context, our research aims to evaluate Turkish - American relations on a holistic approach considering the past and present. In this way, the study was focused with the first meeting of the Ottoman Empire and USA as well as covering the post-proclamation of the Republic.

Turkey-US Relations are elaborated without making distinction between the Republic of Turkey and the Ottoman state to demonstrate permanent process. The data used in the analysis of the study were obtained as a result of the analysis performed by documentary source scanning method. The analyzed material includes official archive records, newspapers and secondary sources, books and articles.

As primary sources, US archives were also used to reflect the US position. In this context, the personal archive of US President Harry S. Truman has been particularly used. Apart from the archive, our primary source was periodicals. Newspapers are at the top of the list in terms of providing effective informations and witnessing history. in addition to archives and periodicals, second hand sources were used by scanning of the literature. The main axis of our study was secondary hand sources. Qualitative data analysis and content analysis methods were used in the study. In this way, the structure of Turkish - American relations has been shown clearly. After World War II in which Turkish foreign policy has been changed dramatically the United States as a strategic ally, has become Turkey's most important supporter against Soviet Russia. After Turkey has become a member of NATO during the Second World War in the process of the cooperation has caused significant changes. Turkey, has been ally with US 
which has been efficiency from 1947 until today by passing from neutral foreign policy to partial policy. In this evaluation, the study aims to reveal how Turkish - American relations, which occupied a very important place in recent history, have evolved in the historical process. In particular, the impact of environmental factors, possessions and approaches of overlapping interests considering Turkey and USA where conditions caused favor and unsavory results for both sides have been examined mutually based on the spiral of the cooperation and conflicts in sense of interests.

The study aims to show how Turkish-American relations, which left behind a two-century process, developed and changed on the axis of conflict and cooperation. US merchant ships arriving in the Mediterranean in the 1800s carried trade by paying taxes to the Garp Ocaklar1 of the Ottoman State in this period. With the signing of agreements between the two countries shortly after the arrival of the US, the Ottoman-US relations became official. After the mutual recognition of the US and Ottoman states, the relations between the two states followed an exit-oriented course. Despite this positive oriented encounter between the Ottoman and the United States, relations have not reached the desired level as a result of the circumstances. Officially diplomatic relationship has been cut after the beginning of the First World War and it was not immediately re-started when Turkish Republic was established. Turkish-American relations, which started again in 1927, did not become an alliance at this level. The relations that started to strengthen in the Second World War and after the Second World War where the United States took the place of the United Kingdom moved towards the alliance. While this rapprochement between the two countries has been accelerated by Truman and the Marshall aid of the US in regards of political and economic momentum it has been enlarged by Turkey's involvement of NATO in 1952 as evolving in the military and security dimensions.

In 1952, along with being a member of NATO, Turkish-American relations which turned into a political, economic and military alliance has been formed according to the Soviet Union's policies during the Cold War. Especially the superior interests of the United States in the period of détente has led to the discussion of Turkey's sacrifice for the first time. It was observed that Turkish-American relations followed a fluctuating course after 1964. The Cyprus question emerging in 1960 resulted to carry out 
military intervention by Turkey in 1974 despite of the United States. Afater that Turkish-American relations has experienced a new departure and conflict. The transformation being in 1980 prevented the uncertainty in Turkish-American relations until the end of the Cold War. The change that started with Turgut Özal's prime ministry in 1983 was reflected in Turkish-American relations and evolved from the conflict to cooperation. Özal's flexible foreign policy continued after the end of the Cold War. After the end of the Cold War largely expected to break Turkish-American relations, contrary to expectations because of the power vacuum in the Middle East region, especially Turkey's recent rapprochement continued. The economic crisis of the early 2000s in Turkey has fostered a closer cooperation process with the US.

After the AK Party came to power, the current convergence in TurkishUS relations continued until the 2003 US operation in Iraq. The resolution as recorded 1st of March Note, which allowed to use Turkish lands for US operation to Iraq has been rejected by Turkish Grand National Assembly. Turkish-American relations, which experienced one of the moments of historical breakdown after the 1st of March Note, began to converge under Barack Obama, who was elected president with the slogan of change after US President Bush. But it was seen that the change was replaced by tension in Obama's second term. During this period, a number of conflicts of interest were experienced with the USA, especially with regard to Syria and Egypt. In particular, due to the United States supports to PKK / YPG arms and ammunition supply in acts of terrorism under the pretext of combating ISID, position against Turkish government in Gezi Park violences, and the lack of assistance to government in the process of 15 July coup d'état, the expected developments did not take place during the Obama period. Turkish-American relations have developed in a fragile process based on conflict. Donald Trump, who became president after Obama, set a new expectation for Turkish-American relations. Since US was being patronage of FETÖ fugitives and disapprove of the extradition by the US despite all of Turkey's request has shown that relationship would be the conflict-prone in the era of Trump too. Due to of ensuring full tractors of weapons and ammunition to the YPG / PKK by US in the era of Trump presidency and lack of the supports of the US as an ally for Turkey's operations in Syria in regards of security has fostered the conflict 
of interests. In this context, Turkish-American relations continued on the axis of conflict during the Trump period. It has been seen that TurkishAmerican relations, which are handled in a historical holistic context, progress in the process of cooperation in the axis of common interest. However, the hegemonic power of the USA caused the dominant power in Turkish-American relations in favor of USA. So often in the face of Turkey's interests it was seen as superior to their own interests to keep the United States. That is why commonly US kept own interests as superior against Turkish interests. When Turkish national interests overlapped with US interests, reciprocal relations has been oriented toward spoil and tension. US always gave significance to own interests and asked Turkey to be absolute partner and supporter even in case of Cyprus where the humanitarian crisis appeared. Otherwise US used its economic and political power against Turkey. Turkey's policy of anti-trusteeship developed against the United States has been increased with a second term of Barack Obama. As a result of this correlation prone conflicts has been strengthened. If US continues to approach Turkey as a strategic partner in case of consisting of interests and ignore Turkish interests when overlapping it may be expected to maintain the conflict of trends in accordance with the historical development for Turkish-American relations and characterize a course of a roller coaster.

\section{Kaynakça / References}

Akbaş, Z., Çaylı, Ş. ve Duman, M. (2018). Amerika Birleşik Devletleri'nin realizm ve idealizm ikileminde ortadoğu politikası: Mısır ve Suriye örnekleri. Social Mentality and Researcher Thinkers Journal, 4(11), 485-502.

Aknur, M. (2012). 27 Mayıs 1960 darbesi ve dış politika. Türk Dış Politikası (19192012). (Ed., Haydar Çakmak). s.549-556. Ankara: Barış Kitap.

Aydın, E. (2018). Geleneksel güvenlik yaklaşımı ile genişleyen ve derinleşen güvenlik yaklaşımının karşılaştırılması. Yerelden Globale Stratejik Araştırmalar, III. (Edited By: Silvius Stanciu, Ali Riza Gökbunar, Turan Gündüz), s.115-129. London: IJOPEC Publication.

Aydın, E. (2019). AB'nin güvenliği ve Türkiye'nin rolü: NATO füze kalkanı, AVRASYA Uluslararası Araștırmalar Dergisi, 7(16), 719-735. 
Çelik, A. H. (2015). Türk dış politikasının niteliği üzerine kavramsal bir tartışma: değerli yalnızlık mı? şuurlu dinamizm mi?. Düzce Üniversitesi Sosyal Bilimler Enstitüsü Dergisi, 5(2), 67-89.

Armaoğlu, F. (2005). 20. yüzyıl siyasî tarihi 1914 - 1995, 15. Baskı. İstanbul: Alkım Yayınevi.

Armaoğlu, F. (1991). Belgelerle Türk-Amerikan münasebetleri, Ankara: Türk Tarih Kurumu Basımevi.

Armaoğlu, F. (1999). Yarım yüzyılın Türk-Amerikan ilişkileri, 1947-1997: bir genel değerlendirme. Çağdaş Türk Diplomasisi: 200 Yıllık Süreç. S.421440 Ankara: Türk Tarih Kurumu Basımevi.

Arık, U. (2011). Kıbrıs. Lefke Avrupa Üniversitesi (LAÜ) Sosyal Bilimler Dergisi, 2(1), 3-21.

Bozdağlıoğlu, Y. (2012). Türkiye-ABD ilişkileri. Türk Dış Politikası (1919-2012). (Ed., Haydar Çakmak), s.465-469 Ankara: Barış Kitap.

Byrnes, J. F. (1948). Açık konuşalım, yalta-Potsdam-Londra-Moskova-Paris 1Londra n- Paris ı- Newyork konferanslarının iç yüzü. (Çev., Semih Yazıcıŏlu). İstanbul: İnkılap Kitabevi.

Çelebi, Ö. (2012). Türkiye-ABD ilişkileri. Türk dış politikası (1919-2012). (Ed., Haydar Çakmak.), s.756-763 Ankara: Barış Kitap.

Doğan, N. (1996). Cumhuriyet öncesi Türk Amerikan ticaret anlaşmaları. İstanbul: Turan Yayincilik.

Erdağ, R. (2017). Normalleşmeden gerilim ve çatışmaya: Türkiye-Suriye ilişkileri. AK Parti'nin 15 Yılı dış politika, s.318-335. İstanbul: SETA Kitapları.

Erhan, Ç. (2004). 1945-1960: Batı bloku ekseninde Türkiye-1 (Demokrat Parti Dönemi-I [1950-1955]). Türk Dış Politikası, Kurtuluş Savaşından Bugüne Olgular, Belgeler, Yorumlar. (Ed., Baskın Oran), Cilt I, 10. Baskı, s. 479575, İstanbul: İletişim Yayınları.

Erhan, Ç. (2004). ABD ve NATO'yla ilişkiler. Türk Dış Politikası, Kurtuluş Savaşından Bugüne Olgular, Belgeler, Yorumlar. (Ed., Baskın Oran), Cilt I, 10. Bask1, s. 681-715, İstanbul: İletişim Yayınları.

Erhan, Ç. (2001). Türk-Amerikan ilişkilerinin tarihsel kökenleri. Ankara: İmge Kitabevi.

Erhan, Ç. (2010). Türk dış politikası'nın güncel sorunları. Ankara: İmaj Yayınevi. Erol, M. (1988). Osmanlı Imparatorluğu'nun Amerika birleşik devletleriyle yaptığı ticaret anlaşmaları. Konya: S.Ü. Fen- Edebiyat Fakültesi Yayınları.

Fendoğlu, H. T. (2002). Modernleşme bağlamında Osmanlı-Amerikan ilişkileri. İstanbul: Beyan Yayınları. 
Feridunoğlu, İ. C. (2017). Hürriyet gazetesi'nce 1964 Johnson mektubu süreci'nde kullanılan dilin milliyetçi söylem bağlamında söylem analizi yöntemiyle incelenmesi. Karadeniz Sosyal Bilimler Dergisi, 9(2), 371 394.

Gencer, A. İ. Örenç, A. F. Ünver, Metin. (2008). Türk-Amerikan Silah Ticareti. İstanbul: Doğu Kütüphanesi.

Gönlübol, M. Ülman, H. (1996). İkinci dünya savaşından sonra Türk dış politikası (1945-1965). Olaylarla Türk Dış Politikası (1919-1995). 9. Baskı. s.543-575 Ankara: Siyasal Kitabevi.

Gönlübol, M., Ö. K, (1996). 1973-1983 dönemi. Olaylarla Türk Dış Politikası (1919-1995). 9. Bask1, s.543-608 Ankara: Siyasal Kitabevi.

Gözen, R. (2012). ABD ile ilişkiler. Türk Dış Politikası 1919-2012. Haydar Çakmak (Ed.). 2. Baskı. s. 379-386, Ankara: Barış Kitap.

Gözen, R. (2012). Truman Doktirini. Türk Dış Politikası (1919-2012). Haydar Çakmak (Ed.). 2. Baskı. s.387-391.Ankara: Barış Kitap

Hale, W. (2003) Türk dış politikası 1774-2000. Çev.Petek Demir. İstanbul.

Hary S. Truman Arşivi. Draft suggestions for President's Message to Congress on Greek Situation, (March 3, 1947). trumanlibrary.org. Subject File, J.M. Jones Papers. 24.09.2018 tarihinde http://www.truman-library.org/whistlestop/study_collections/doctrine/large/documents/pdfs/6-9.pdf\#zoom=100

İnat, K., Caner, M. (2017). Türk-Amerikan ilişkilerinde 'eksen' sorunu. $A K$ Parti'nin 15 Yılı Dış Politika. S.109-134. İstanbul: SETA Kitapları.

Kanat, K. B. Michalke, K. L. Hannon, J. (2017). Türkiye-ABD ilişkileri ve yeni $A B D$ yönetimi. Siyaset, Ekonomi ve Toplum Araştırmaları Vakfı (SETA).

Karakaş, N. Türk-Amerikan siyasi ilişkileri (1939- 1952). Atatürk Araştırma Merkezi.

Keyvan, Ö. Z. (2011). Stratejik ortaklıktan model ortaklığa türk-amerikan ilişkileri ve büyük ortadoğu projesi. Türk Dış Politikasında Strateji Arayışları. Drl. Mehmet Seyfettin Erol. S.95-118. Ankara: Barış Kitap.

McGhee, G. (1992). ABD-Türkiye-NATO-Ortadoğu. Çev., Belkıs Çorakçı. Bilgi Yayınevi.

Oran, B. (2002). Batı bloku ekseninde türkiye 2. Türk Dış Politikası, Kurtuluş Savaşından Bugüne Olgular, Belgeler, Yorumlar. Ed., Baskın Oran, Cilt II, 4. Baskı, s. 9-33. İstanbul: İletişim Yayınları.

Sander, O. (1996). Siyasi tarih 1918-1994. 5. Baskı. İmge Kitabevi, 1996. 
Sezer, D. B. (1999). Soğuk savaş dönemi ve türkiye'nin ittifaklar politikası. Çağdaş Türk Diplomasisi: 200 Y1llık Süreç. s. 441-464.Ankara: Türk Tarih Kurumu Basımevi.

Sönmezoğlu, F. (2006). II. Dünya savaşı'ndan günümüze türk dış politikası. İstanbul: Der Yayınları.

Sönmezoğlu, F. (2016). Son onyıllarda Türk dış politikası 1991-2015. İstanbul: Der Yayınları.

Şafak, N. (2003). Osmanlı-Amerikan ilişkileri. İstanbul: Osmanlı Araştırmaları Vakf1.

Toker, M. (1971). Türkiye üzerinde 1945 kâbusu. Ankara: Akis Yayınları.

Turaman, O., Çelik, A. H. (2018). Türkiye ve ABD'nin Ortadoğu dış politikası: Irak ve Suriye örnekleri üzerinden çatışan ve örtüşen değerler ikilemi. Düzce Üniversitesi Sosyal Bilimler Enstitüsü Dergisi, 8(1), 116-138.

Uslu, N. (2003). The Turkish-American relationship between 1947 and 2003. New York: Nova Science Publishes, Inc.

Uslu, N. (2012). Türkiye - ABD İlişkileri. Türk dış politikası 1919-2012. Ed. Haydar Çakmak. 2. Baskı, s. 690-695, Ankara: Barış Kitap.

Uzgel, İ. (2002). ABD ve NATO'yla ilişkiler. Türk Dış Politikası, Kurtuluş Savaşından Bugüne Olgular, Belgeler, Yorumlar. Ed., Baskın Oran. Cilt II, 4. Baskı. s. 243-325. İstanbul: İletişim Yayınları.

Uzgel, İ. (2010). Diş politikada AKP: stratejik konumdan stratejik modele, AKP Kitabı. Drl. İlhan Uzgel- Bülent Duru. 2.Baskı, s.357-380. İstanbul: Phonenix Yayınevi.

Ülman, A. H. (1961). Türk-Amerikan diplomatik münasebetleri (1939-1947). Ankara: Sevinç Matbaası.

Ülman, H. (1961). İkinci cihan savaşının başından truman doktrinine kadar TürkAmerikan diplomatik münasebetleri 1939-1947. Ankara: Ankara Üniversitesi Siyasal Bilgiler Fakültesi Yayınları.

Ünlü, T. (2012). Kıbrıs sorunu ve 1974 müdahalesi. Türk Dış Politikası 19192012. Ed. Haydar Çakmak. 2. Baskı, s. 681-689. Ankara: Barış Kitap.

Veysel, B., Erhan Ö. (2016). Kamu politikası Türkiye'de uyuşturucu ile mücadelede uygulanan politikalar ve toplumsal algı. Konya: Çizgi Kitapevi.

Weisband, E. (1974). İnönü'nün dış politikası. Çev., M. Ali Kayabal. Milliyet Yayınlar1.

Süreli Yayınlar

Akşam Gazetesi

Ayın Tarihi 
Karar Gazetesi

Ortadoğu Gazetesi

Star Gazetesi

Türkiye Gazetesi

Yeni Şafak Gazetesi

Kaynakça Bilgisi / Citation Information

Akbaş, Z., Çelik, A.H. ve Duman, M., (2019). İkinci Yüzyılında İşbirliği ve Çatışma Sarmalında Türk- Amerikan İlişkileri. OPUS-Uluslararası Toplum Araştırmaları Dergisi , 13(19), 2226-2258. DOI: 10.26466/ opus.532884 